Escuela de Ciencias Sociales y Humanidades, UNED, C.R.

URL: http://investiga.uned.ac.cr/revistas/index.php/espiga/index

ISSN: $1409-4002 \cdot \mathrm{e}-I S S N$ : 2215-454X

\title{
Las ordenanzas de una cofradía de sangre: la cofradía de San Nicolás de Tolentino, $1641^{1}$
}

\section{Verónica Jerez-Brenes}

Centro de Investigaciones Históricas de América Central CIHAC-UCR, Profesora de la Escuela de Estudios Generales, Sección Historia de la Cultura. Universidad de Costa Rica. Costa Rica. lotorojo@gmail.com; veronica.jerezbrenes@ucr.ac.cr

Recibido: 13 de octubre, 2015 • Aceptado: 27 de mayo, 2016 • Corregido: 31 de agosto, 2016

\section{RESUMEN}

(Find the abstracts in English and French at the end of the article)

El presente artículo expone brevemente las ordenanzas que condujeron al establecimiento de la Cofradía de San Nicolás de Tolentino en 1641 en la ciudad de Cartago, Costa Rica, de acuerdo con lo anotado en el libro de la Cofradía.

Palabras clave: Cartago, cofradía, ordenanzas, santos patronos, Costa Rica

"Manda el santo Concilio a todos los Obispos, y demás personas que tienen cargo y obligación de enseñar, que instruyan con exactitud a los fieles ante todas cosas, sobre la intercesión e invocación de los santos, honor de las reliquias, y uso legítimo de las imágenes, según la costumbre de la Iglesia Católica y Apostólica”.

El sacrosanto y ecuménico Concilio de Trento, traducido al idioma castellano por Ignacio López de Ayala. Agregase el texto latino corregido según la edición auténtica de Roma, publicada en 1564. Sesión XXV, página 355.

\section{Formato de citación según APA}

Jerez-Brenes, V. (2016). Las ordenanzas de una cofradía de sangre: la cofradía de San Nicolás de Tolentino, 1641. Revista Espiga. Vol. XV, (32), 63-80.

\section{Formato de citación según Chicago}

Jerez-Brenes, Verónica. «Las ordenanzas de una cofradía de sangre: la cofradía de San Nicolás de Tolentino, 1641». Revista Espiga. XV. N. ${ }^{\circ} 32$ (2016): 63-80.

1. El presente artículo nació como una ponencia presentada en el XII Congreso Centroamericano en Historia que fue modificado y corregido para dar como resultado este documento. 


\section{Aspectos generales}

La provincia de Costa Rica, en los aspectos político-administrativos, formaba parte del Reino de Guatemala, a su vez parte del Virreinato de Nueva España. En lo religioso, estuvo vinculada a la Diócesis de Nicaragua, creada en 1531 y tenía su sede en la ciudad de León, y en 1545 se incorpora a esta jurisdicción a Costa Rica. Durante el período colonial e inicios del republicano, todos los asuntos religiosos debían ser tramitados vía León, pues no fue sino hasta 1850 que Costa Rica contó con diócesis propia².

En la entonces capital colonial de la provincia de Costa Rica, la ciudad de Cartago, así como en el resto del territorio, comenzaron a nacer las cofradías ${ }^{3}$ como parte de las directrices emanadas del Concilio de Trento (1545-1563); en el cual se impulsaban las devociones a los santos como personas que por sus características de santidad durante su paso en la tierra, se convertían en intercesores ante Dios por las causas que les solicitaran sus fieles ${ }^{4}$. Las distintas devociones fueron introducidas al Nuevo Mundo por medio de las órdenes religiosas y de las preferencias personales de los españoles que se asentaron en la provincia durante el periodo de exploración y conquista de los territorios. Es así que, santos como Santiago ${ }^{5}$, patrono de España -y al que se le atribuye su intercesión en el proceso de reconquista de la península- toman un papel protagónico en la onomástica de las ciudades del Nuevo Mundo; por lo cual la confianza en el patronato de los santos funcionaba tanto a nivel personal como colectivo, esto por cuanto se convertían en los protectores de los pueblos y ciudades a lo largo de todo el reino español.

\section{La cofradía}

Una de las formas colectivas de devoción son las cofradías. Estas eran asociaciones voluntarias de laicos que se encontraban reguladas por el derecho canónico debido a que estaban favorecidas con indulgencias otorgadas desde Roma; motivo por el cual debían solicitar la licencia para su erección ${ }^{6}$. Las cofradías se encargaban de formas de culto

2. Para más información sobre este tema, consultar el artículo de Carmela Velázquez Bonilla, "Los cambios político-administrativos en la diócesis de Nicaragua y Costa Rica. De las reformas borbónicas a la independencia", Hispania Sacra LXIII, N. ${ }^{\circ}$ 128, (julio-diciembre 2011): 569-593.

3. En la historiografía costarricense, quienes han trabajado este tema se han centrado en dos perspectivas principalmente: las cofradías indígenas y la extinción de las cofradías como parte de las reformas borbónicas. Si bien en los trabajos acerca de la religiosidad y las devociones se hace mención de las cofradías, estas aparecen como parte del contexto religioso colonial en general.

4. Si bien la Iglesia estimulaba la devoción a los santos, debía ser muy cuidadosa para que los fieles no cayeran en una tergiversación o en formas de culto popular, debido a que los santos por sí solos no "hacen milagros" es Dios quien actúa mientras que los santos lo que hacen es interceder. Para cada causa se tiene un santo o santa en particular, en el que podríamos decir que es especialista.

5. Santiago el Mayor, uno de los 12 apóstoles y, según la tradición religiosa española, se le aparece en sueños a Ramiro I y le dice que él será el patrono de España, por lo que cuando lo invoca durante la batalla de Clavijo en 833, se dice que aparece montado en un caballo blanco ayudando a la derrota a los musulmanes; es de ahí que toma el nombre de "Matamoros". Traído su patronazgo a las Américas, se le atribuye su intervención en la lucha contra los indígenas insumisos y se convierte en el patrono de ciudades como Santiago de los Caballeros en Guatemala, Santiago de Chile, Santiago de Guayaquil y en Costa Rica, en Cartago se encuentran las ruinas del antiguo templo.

6. Diccionario de derecho Canónico. (París: Librería Rosa y Bouret, 1854), 254. 
público y por supuesto, la pervivencia de la devoción al santo patrono bajo el cual se agrupan. La cofradía como institución, se puede definir como:

Asociación piadosa, caritativa, asamblea de personas unidas por un lazo profesional, corporativo u otro; congregación o hermandad que forman algunos devotos, con autoridad competente para ejercitarse en obras de piedad; asociación, gremio, compañía de gentes, para un fin determinado; vecindario, unión de personas o pueblos congregados entre sí para disfrutar de privilegios. ${ }^{7}$

Si bien en el origen de la cofradía como institución existen debates acerca de la temporalidad de su aparición (en relación con la Collegia Romana o en la Europa Medieval ${ }^{8}$ ), para los fines de esta investigación se parte con su presencia en tierras americanas. Desde su regulación en el Derecho Indiano (a partir de 1680) se establece que estas debían de ser fundadas por medio de erección canónica. Cada cofradía debía enviar la petición de permiso de erección a la autoridad eclesiástica correspondiente y esperar a recibir su aprobación. Una vez aprobada, adquiría una condición de personería jurídica eclesiástica, por lo cual sus bienes y sus libros estarían sujetos a revisiones periódicas por parte del Juez Eclesiástico designado para tal fin.

Para el año de 1641, un grupo de residentes de la ciudad de Cartago deciden solicitar la licencia para la erección de una cofradía en honor a San Nicolás de Tolentino. Según los datos obtenidos, luego de la revisión de los documentos sobre cofradías presentes en el Archivo Eclesiástico 9 , las devociones marianas en Cartago fueron las más numerosas con 10 cofradías, seguidas por las que corresponden a misterios cristológicos con 5 y las que impulsaban la devoción a los santos en general con 4; siendo la más antigua de esa categoría la de San Nicolás de Tolentino. Estos datos brindan pistas acerca de las preferencias devocionales de los cartagos entre los siglos XVI y XIX, el tipo de advocación escogido o el patrono. Además, habla de las preferencias personales de la élite, debido a que por la naturaleza de la cofradía como forma de organización, la libre elección del patrono al cual se asocia, y que no sea un santo franciscano es significativo. No obstante, la proliferación de santos patronos en una misma ciudad no era algo inusual ni un fenómeno aislado. Al respecto Pierre Ragón indica que "(...) la diversidad de las amenazas susceptibles de poner en jaque a los frágiles equilibrios urbanos y la variedad de los actores interesados en la promoción de nuevos santos patronos" ${ }^{10}$, por eso el que coexistieran diversas cofradías cada una con un patronazgo particular dentro de una misma ciudad o villa era una práctica común, sobre todo, si el patrono que se había escogido era calificado como poco eficaz por sus devotos.

7. Flavio Rojas Lima, La cofradía. Reducto cultural indígena (Guatemala: Litografías Modernas, 1988), 41.

8. Al respecto del origen puede consultarse el artículo de Claudia Quirós acerca de las cofradías indígenas en Nicoya o la tesis de Ligia Carvajal y Guillermo Arroyo.

9. Archivo Histórico Arquidiocesano Bernardo Augusto Thiel (AHABAT), Cofradías Cartago, cajas N. ${ }^{\circ} 1$ a 87; los datos cubren desde $1^{a}$ más antigua que es la de Nuestro Amo en 1587 la cofradía de San Juan de Dios de 1858

10. Pierre Ragón, "Los santos patronos de las ciudades del México central (siglos XVI y XVII)", Historia mexicana, N. ${ }^{\circ}$ 206, (2002): 369. 


\section{El santo patrono}

San Nicolás de Tolentino (1246-10 septiembre 1306) fue un religioso italiano que ingresó a la orden de los agustinos a los 19 años. Se dedicó a la predicación y la caridad, vivió la mayor parte de su vida en la ciudad de Tolentino, de ahí toma su nombre. Fue canonizado en 1446 por el Papa Eugenio IV; su fiesta se celebra el 10 de septiembre, y según se dice su cuerpo fue encontrado incorrupto luego de 40 años, lo cual añadió un aspecto místico a su persona. En esa ocasión se le cortan los brazos para convertirlos en reliquias, las cuales todavía se conservan en la ciudad de Tolentino en la actual Basílica, junto con estos relicarios se conserva un cáliz la sangre que al parecer emanó de las heridas en ese momento en el año 1345.

La importancia de las reliquias como parte de las formas devocionales viene dado por las mismas directrices Tridentinas:

(...) instruyan también a los fieles en que deben venerar los santos cuerpos de los santos mártires, y de otros que viven con Cristo, que fueron miembros vivos del mismo Cristo, y templos del Espíritu Santo, por quien han de resucitar a la vida eterna para ser glorificados, y por los cuales concede Dios muchos beneficios a los hombres; de suerte que deben ser absolutamente condenados, como antiquísimamente los condenó, y ahora también los condena la Iglesia, los que afirman que no se deben honrar, ni venerar las reliquias de los santos; o que es en vano la adoración que estas y otros monumentos sagrados reciben de los fieles; y que son inútiles las frecuentes visitas a las capillas dedicadas a los santos con el fin de alcanzar su socorro. ${ }^{11}$

No obstante, para las cofradías no siempre existió la posibilidad de tener acceso a reliquias de su santo patrón, por ese motivo, las hermandades se encargaron de que la imagen que lo personificara no careciera de ninguno de los elementos representativos, por ejemplo, trajes o emblemas.

San Nicolás de Tolentino se asocia como abogado de las almas del purgatorio porque en sueños se le presentó un hermano de la orden que le muestra los sufrimientos que está padeciendo en el purgatorio; ante esto, San Nicolás decide ofrecer misas, oraciones y ayuno en rogativa por las almas que se encuentran ahí. El purgatorio ${ }^{12}$ es el sitio o estado en el cual quedan las almas de quienes encontrándose en gracia de Dios (bautizados) por su condición de pecadores no pueden entrar al Paraíso. En la escatología agustiniana se parte de la premisa establecida por San Agustín en que no solo es un lugar, sino un estado de las almas y que todas poseen no solo por los pecados cometidos, sino también por ser descendientes de Adán y Eva.

Luego de la muerte de la carne, sobreviene el juicio individual, si no se expiaron todas las culpas en vida, las que queden por limpiar deben hacerse en el Purgatorio y luego de esto es que se puede ver a Dios. Con el Concilio de Trento queda establecida la noción

11. El sacrosanto y ecuménico Concilio de Trento, traducido al idioma castellano por Ignacio López de Ayala. Agregase el texto latino corregido según la edición auténtica de Roma, publicada en 1564. Sesión XXV, 328-329.

12. Si bien se manejaba el término, el concepto como tal, del sitio de purga de las culpas (y su ubicación) se debaten largamente como parte de la teología católica. 
medieval de que existe la posibilidad de salir del Purgatorio, ya sea por méritos propios (que el alma expió todos los pecados) o por que los vivos por medio de oraciones o de la donación de útiles espirituales que colaboraron en su salvación ${ }^{13}$.

Se puede decir que ser el abogado de las almas del purgatorio le viene otorgado a San Nicolás de Tolentino no solo por un episodio particular de su vida, sino por la escatología propia de la orden a la cual pertenece. De igual forma se le considera un santo taumaturgo ${ }^{14}$.

Entre las tradiciones que se conservan se encuentra la del "pan de San Nicolás", esta se refiere a un episodio de su vida, en el cual estando gravemente enfermo se le presenta la Virgen María y le indica que debe comer un trozo de pan mojado en agua para recobrar la salud, acto que ejecuta en obediencia y que luego de recuperarse practica con los enfermos a los que visita. Sin embargo, se puede indicar que esta práctica no se encuentra generalizada al contrario de devociones a otros santos en las cuales se reparte $\operatorname{pan}^{15}$ debido a que la bendición del pan de San Nicolás quedó reservada como práctica que únicamente se le concede a la orden de los agustinos ${ }^{16}$. Se podría inferir que la bendición del pan de San Nicolás no llegó a practicarse debido a que Costa Rica fue un territorio que estuvo casi exclusivamente en manos de la orden de los franciscanos observantes y estos no estaban facultados para llevarla a cabo.

Cabe subrayar, que la fundación de una cofradía con un patrono agustino destaca en una provincia eminentemente franciscana. Es más, su establecimiento representó un posible sitio de acogida para los religiosos agustinos, situación que preocupó a los franciscanos y según consta para $16788^{17}$, los franciscanos inician un proceso en el cual se oponen a que se funde en la ciudad de Cartago un convento agustino. Uno de los argumentos utilizado por Fray Ambrosio Salado de Ordiales, guardián del convento de Cartago, fue la pobreza de la ciudad y la incapacidad de los vecinos para mantener a dos órdenes mendicantes; no obstante, como existía la ermita de la cofradía de San Nicolás, Fray Manuel de San Gabriel se asienta allí mientras llegaba la licencia para la fundación del convento agustino. Finalmente y luego de todas las objeciones presentadas por los franciscanos, el fraile agustino no se queda en Cartago, sino que se ubica en el convento que la orden tiene en Panamá. El segundo momento en el que se puede encontrar a un agustino en Costa Rica fue entre los años de 1822 y 1824 que Fray José de San Simón Franco estuvo como encargado del pueblo de Ujarrás. Esta idea de que no hubo miembros de otras órdenes

13. Concilio de Trento, Sesión XXV, 327.

14. Designación que se utiliza para los santos que realizan milagros por medio de la intervención divina, en el caso de San Nicolás, con la imposición de manos.

15. Como es el caso de las festividades de San Vicente, San Antonio Abad y San Martín de Porres que se celebran en Costa Rica y todavía en la actualidad se conserva la costumbre de repartir trozos de pan entre las personas que asisten a las actividades religiosas.

16. Al respecto se puede consultar la página la información que brinda la Basílica de San Nicolás de Tolentino por medio de su página web: http://www.sannicoladatolentino.it/i-panini-benedetti-di-san-nicola-.html

17. Al respecto se puede consultar: Ricardo Fernández Guardia, Colección de documentos para la historia de Costa Rica. Tomo VIII (Barcelona: Imprenta viuda de Luis Tasso, 1907), 359-375. 
religiosas se encuentra muy difundida como es el caso de los textos de Víctor Manuel Sanabria ${ }^{18}$.

Iconográficamente se reconoce a San Nicolás por vestir el hábito negro de los agustinos, ya fuera únicamente con su cinturón o con un bordado de una estrella en el pecho ${ }^{19}$ (Imagen N. ${ }^{\circ} 1$ ), esta representación simbólica corresponde a un pasaje de su vida en que según la tradición, cuando acudía a la iglesia por las noches lo guiaba una estrella. Se incluyen entre sus símbolos el lirio $^{20}$ o el crucifijo. El platón con un ave viva que lleva en la otra se refiere a un pasaje en el cual, estando muy enfermo y debido a lo estricto de sus ayunos, sus hermanos frailes le llevan unas aves cocinadas, las cuales a pesar de estar asadas escaparon volando. Todos estos símbolos son determinantes para su representación e identificación y la cofradía que se fundó en Cartago no tardó en adquirir todos estos elementos para ser utilizados durante las procesiones, como se ve más adelante.

\section{La constitución de la cofradía}

La solicitud de licencia para la erección de la cofradía de San Nicolás de Tolentino se envió para la aprobación del obispo de León, en

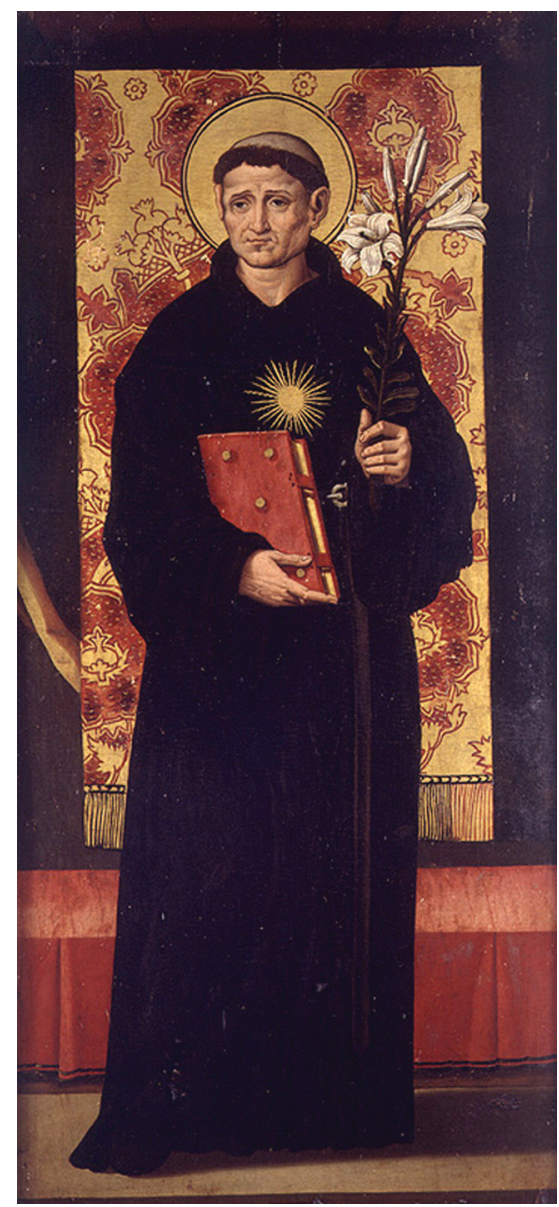

Imagen 1. San Nicolás de Tolentino. La obra representa al religioso agustino San Nicolás de Tolentino (12451305). Dimensiones: Alto $105 \mathrm{~cm}$ (41.3”). Ancho $48 \mathrm{~cm}$ (18.9”). Artista: Miguel del Prado, pintor español, renacentista, trabajo del periodo 1518-1537. Localización: Valencia. Fuente: Museo de Bellas Artes de Valencia. Obra de dominio público; recuperada de: https://commons.wikimedia.org/wiki/File:Miguel_del_prado-san_ nicolas_tolentino.jpg

18. Sanabria, expresa al respecto: “Por qué sólo los franciscanos se establecieron en Costa Rica? La respuesta la hallamos en la pobreza, mal crónico y al parecer irremediable de Costa Rica durante la colonia. Era imposible que pudieran mantenerse en nuestra tierra las comunidades religiosas consagradas a la vida conventual, a la beneficencia o a la enseñanza, que suponen un relativo bienestar económico de la población a cuyo servicio están". Víctor Manuel Sanabria, Reseña histórica de la Iglesia en Costa Rica de 1502 hasta 1850 (San José: DEI, 1984): 73.

19. Depende de la representación puede ser una estrella o el hábito lleno de estrellas.

20. Esta flor se asocia a la pureza y la inocencia; el triunfo de la santidad en contra la tentación carnal. Es una iconografía con la cual se asocia a la Virgen María desde la Edad Media "Como lirio entre cardos es mi amada entre las doncellas (Cant., 2,2)" y a otros santos como San José, Santo Domingo de Guzmán y San Antonio de Padua. 
ese momento con sede vacante ${ }^{21}$, por lo que lo firmó el deán del cabildo de León don Francisco de Berico, y consta en documento con fecha del 20 de setiembre de 1640 en que vistas las ordenanzas "hechas en veinte días del mes de mayo pasado de este presente año" 22 se concede licencia y facultad, con la firma del documento de aprobación queda concluido el proceso y por ende legalizado el estatus de la hermandad, por lo que ya para 1641 inicia el libro de la cofradía (Imagen N. ${ }^{\circ}$ 2).

Su estatuto consta de 16 ordenanzas ${ }^{23}$ en las cuales se establecen los aspectos administrativos y organizativos de la misma, sus miembros, festividades, la manera y orden en que se llevarán a cabo las procesiones.

Un elemento a destacar, es que se indica que la cofradía será "de sangre", motivo por el cual la podemos clasificar como de tipo penitencial. Las cofradías de sangre son aquellas en las cuales sus miembros, como una forma de expiar las culpas y de recordar la pasión y muerte de Jesucristo ${ }^{24}$, se auto flagelan en un ejercicio en que se equiparaba la

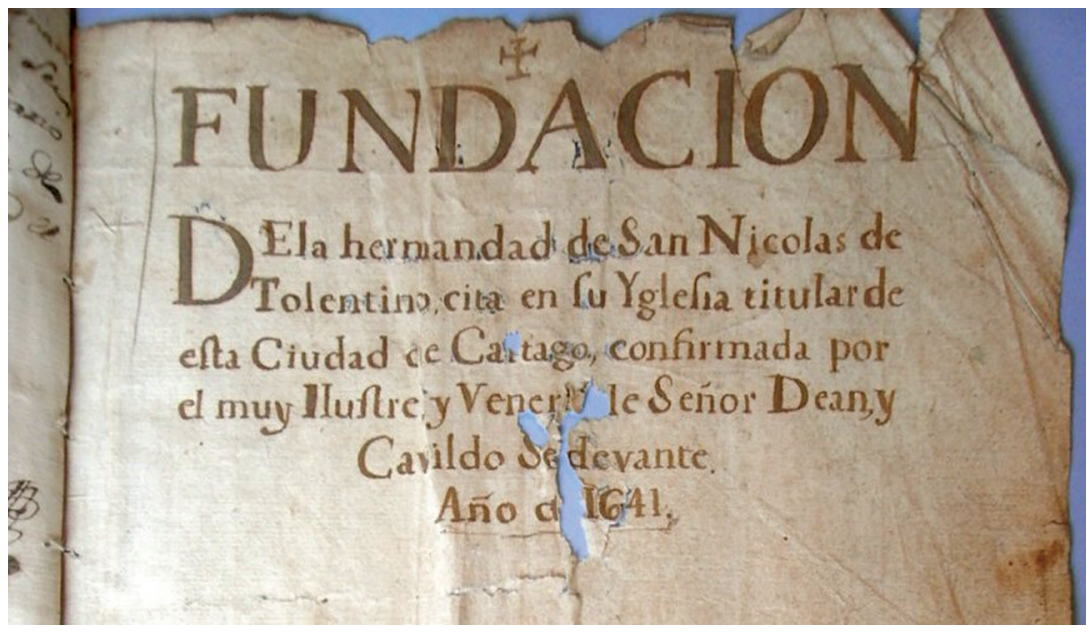

Imagen 2. Libro de La Cofradía San Nicolás de Tolentino 1641. Detalle del folio de portada. Cofradías Cartago caja N. ${ }^{\circ}$ 3. Fuente: Archivo Histórico Arquidiócesano Bernardo Augusto Thiel (AHABAT), Cofradías Cartago Caja N. ․ 3. Fotografía: Verónica Jerez Brenes 2012.

21. En ese momento se encontraba la "sede vacante" porque la diócesis no contaba con un obispo nombrado, pues en 1639 había fallecido don Fernando Núñez Sagredo y Fray Alonso de Briceño tomó posesión hasta 1646.

22. Archivo Histórico Arquidiocesano Bernardo Augusto Thiel (AHABAT), Cofradías Cartago Caja N. ${ }^{\circ} 3$. Cofradía San Nicolás de Tolentino.

23. Según lo indicado en el Diccionario de autoridades, las ordenanzas son los estatutos que se manda observar; este nombre se aplica a las que están hechas para el régimen de los militares, y buen gobierno en las Tropas, o para el de alguna ciudad o comunidad. En este caso serán las que se apliquen para el funcionamiento de la cofradía.

24. Jesús Miguel Palomero Páramo, "Las procesiones de "sangre" en Sevilla y Nueva España. A propósito de una pintura mural en la iglesia conventual de Huexotzingo," en Actas de las I Jornadas de Andalucía y América, Instituto de Estudios Onubenses: Sevilla: S.E, 1981, 315. 
devoción particular con el nivel de castigo y la visión de la severidad de las heridas. Esta práctica provino de España, y en lugares como México y Filipinas todavía se practica.

Como en 1641, la cofradía no posee ermita ni iglesia propia, se asienta inicialmente en el templo de la parroquia de Cartago ${ }^{25}$ y ya para el año de 1643 cuentan con su templo y en 1675 se le concede licencia para la colocación del Santísimo Sacramento ${ }^{26}$ (Imagen N. ${ }^{\circ}$ 3). De acuerdo con el Obispo Morel de Santa $\mathrm{Cruz}^{27}$ en su visita pastoral de 17511752, había cuatro iglesias en Cartago, todas fundadas sobre horcones, con paredes de adobe y techadas con teja, siendo la de San Nicolás la más humilde y reducida.

En su primera ordenanza se estipula que contará con cuatro diputados ${ }^{28}$, un mayordomo $^{29}$ un prioste o alcalde, se destaca que será mayordomo "el alcalde ordinario más

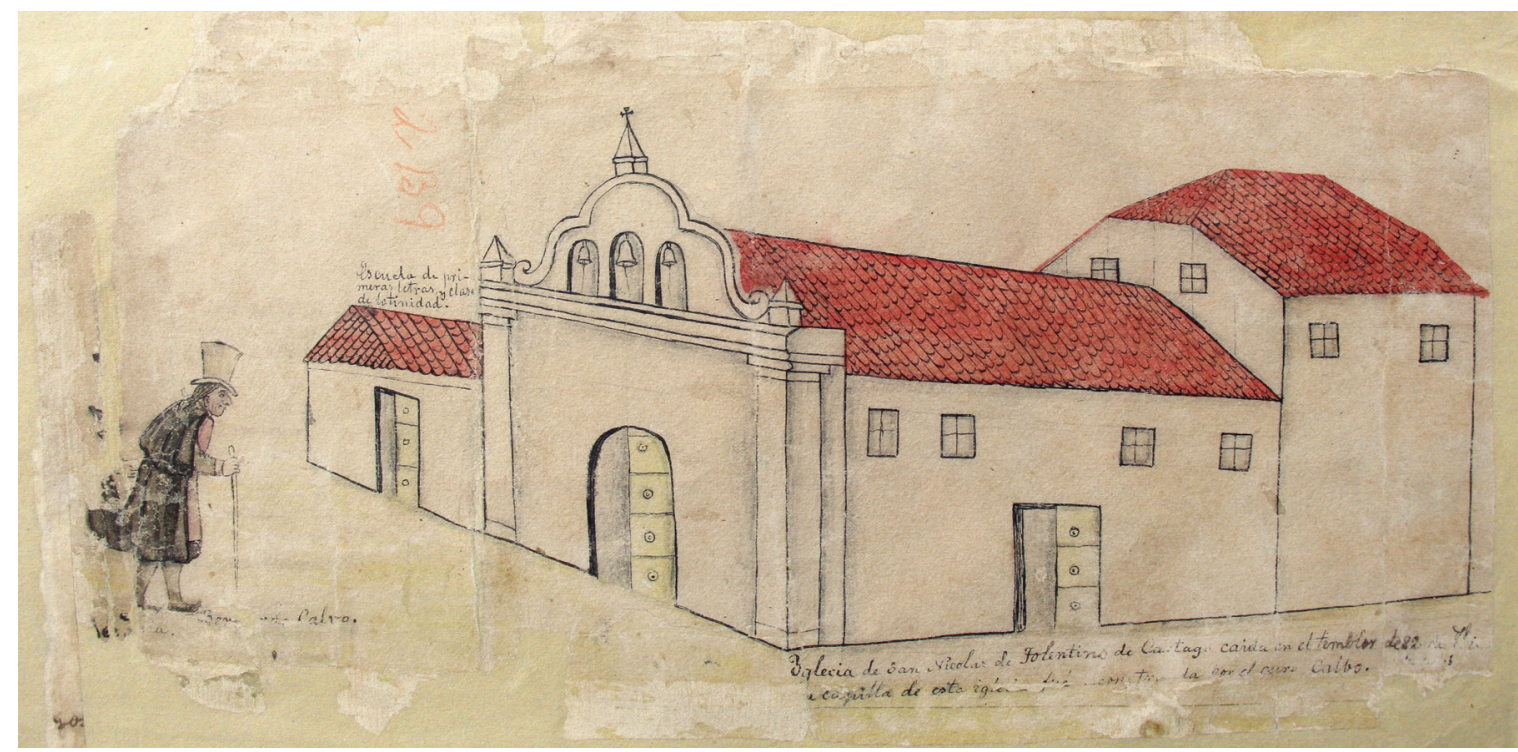

Imagen 3. Iglesia de San Nicolás de Tolentino. Fuente: Álbum de Figueroa, Archivo Nacional de Costa Rica.

25. Razón por la cual el libro de la cofradía de San Nicolás se conserva junto con los libros de la cofradía de Nuestra Señora de los Ángeles por compartir en sus inicios la parroquia.

26. AHABAT, Cofradías Cartago Caja N.․ 3. Cofradía de San Nicolás de Tolentino.

27. "Visita apostólica, topográfica, histórica y estadística de todos los pueblos de Nicaragua y Costa Rica, hecha por el ilustrísimo señor Pedro Agustín Morel de Santa Cruz, Obispo de la Diócesis en 1751 y elevada al conocimiento de S.M. Católica Fernando VI el 8 de setiembre de 1752," en Revista Conservadora, Managua, Editorial Alemana, no 82, julio 1967, pp. 1-43.

28. De acuerdo con la definición del Diccionario de autoridades, Tomo IV 1734, un diputado es aquella persona nombrada y destinada por un cuerpo o comunidad, para que en su nombre y con su autoridad ejecute alguna cosa, en este caso, lo hará en nombre de la cofradía. Por lo general se encargan de preparar el templo durante las festividades, hacer la fierra del ganado de la cofradía por mencionar algunas de sus funciones más comunes.

29. Nombre que recibe el oficial que se nombra en las congregaciones o cofradías, para la distribución de los gastos, cuidado y gobierno de las funciones. Si bien hay quienes cofunden este puesto con el de diputado, la diferencia es que el mayordomo tiene la responsabilidad de llevar la contabilidad de los dineros de la cofradía y dar cuenta y justificación de lo gastado. 
antiguo y que en caso de que no pudiere tomar el puesto puede serlo el más moderno”, lo cual nos refiere a que debe ser un miembro reconocido de la élite de Cartago. Se debe aclarar, que si bien es cierto el hecho de que miembros de otros grupos étnicos podían integrarse en la cofradía de San Nicolás de Tolentino, no quiere decir que todos los puestos en la cofradía tuvieran el mismo nivel en la jerarquía social o al menos cuando esta iniciaba. Por ejemplo, el puesto de mayordomo era de más responsabilidad y de mayor prestigio, tanto así, que en los libros siempre se consigna el nombre del mayordomo por ser el encargado del manejo del dinero y la gestión de venta de bienes (ganado). Además, de llevar los libros en que se anotaban las personas pertenecientes a la cofradía. Su labor era fiscalizada por medio de la revisión de los libros y en caso de malos manejos era llevado a juicio. El resto de los puestos podían ser ocupados por personas pertenecientes a otras etnias ${ }^{30}$ sobre todo si detentaban algún grado militar, por lo que no se puede decir que eran indígenas o mulatos pobres los que en primera instancia llegaban a ser mayordomos, si no que para ellos se destinaban los puestos de diputados, tal como se explica más adelante para el caso de los diputados de naturales. Sin embargo, con el paso del tiempo y la aplicación de las Reformas Borbónicas, con respecto a los bienes píos, cuando las cofradías de blancos dejaron de tener preeminencia económica pasaron a manos de indígenas, mestizos y mulatos.

En su segunda ordenanza indica la fecha en la que se reunirán para la elección de los diputados, la cual será en las vísperas de la festividad del santo el 10 de setiembre. Por lo general se llevaba a cabo el día antes o sea 9 de septiembre, para un nombramiento que será anual. Es el momento en que se darán las cuentas de lo gastado. En caso de que alguno de los diputados, mayordomo o prioste falte sin legítima razón de hacerlo, tendrán que pagar una pena equivalente a 4 libras de cera a favor de la cofradía ${ }^{31}$. No obstante, aunque falten miembros, la elección que se realiza con los presentes será legítima y aceptada, esto último queda respaldado porque contará con la presencia y confirmación del Juez Eclesiástico, Vicario o a falta de estos, el cura de la ciudad de Cartago; que no tendrá voto al momento de la elección pero estará como encargado de fiscalizar el proceso.

Por ejemplo, el 9 de setiembre de 1642, se reúnen en forma de cabildo, el Lic. Baltazar de Grado que de acuerdo con Sanabria fue "el primer costarricense que alcanzó la dignidad del sacerdocio" 32 y participó activamente en la cofradía tanto en su calidad de Comisario del Santo Oficio como posteriormente en otros cargos; el capitán Justo de Salazar, Luis Machado y Julián de Acuña; nombrando como prioste al alférez Antonio de Acuña, alcalde ordinario más antiguo de la ciudad de Cartago (ya que el capitán Juan de Sanabria Maldonado, el alcalde más antiguo no es cofrade), por diputados nombran al capitán Jerónimo de Retes, al alguacil mayor José de Sandoval Ocampo, a Luis González Villalón y a Esteban Rodríguez. El mayordomo será el Lic. Baltazar de Grado. Dicho cabildo tiene el visto bueno del señor Vicario Provincial y lo firman los presentes. Bajo

30. Excepto en el caso de los indígenas, que claramente en las ordenanzas se indica que no podían ser electos ni diputados ni mayordomos; prohibición que se modificó con el pasar del tiempo. AHABAT, Cofradías Cartago Caja N. ${ }^{\circ}$ 3. Cofradía de San Nicolás de Tolentino.

31. La cera es un bien preciado no solo por su precio si no porque es el elemento para la iluminación del templo durante las festividades, las misas y por supuesto velar la imagen del santo.

32. Sanabria, "Reseña Histórica de la Iglesia en Costa Rica", 133. 
esta fórmula trascurren las sucesivas convocatorias para la elección, siendo muchos de los miembros reelectos en los años venideros.

Anualmente, quedaba registrado en los libros que los hermanos de la cofradía se reunían dos veces al año; como ya se mencionó, una vez en la víspera para la elección y otra que variaba entre los meses de abril y mayo (dependiendo de la fecha de la Cuaresma y la Semana Santa) y que correspondía a la asignación de las insignias y el orden de la procesión. De este tipo de reuniones solo queda el informe de la convocatoria, el dato de los presentes o ausentes y su firma; pero no se menciona quién será el encargado de llevar cada uno de los elementos procesionales, lo cual habría sido un detalle interesante para conocer quiénes tenían una participación más activa en la parte penitencial, pero como esto se debía mantener en relativo secreto, no se registra en el libro, ya que durante las procesiones los hermanos se vestían con túnicas y capirotes que los uniformaban y la identidad de quienes desfilaban y el orden de estos no se suponía que fuera motivo de alarde, muy a pesar de que son actividades que dan prestigio social y moral a sus participantes.

En la tercera ordenanza, se establece cómo se ha de llevar a cabo la festividad del santo, que será con toda la formalidad. Inicia con la víspera, la procesión y el sermón. Todos los cofrades están obligados a participar en los oficios religiosos y se le dará al cura 20 reales por el sermón, al sacristán 4 reales y al predicador 5 pesos, esto porque indican que la cofradía es pobre. Además, más adelante en las ordenanzas se establece que para la fiesta patronal todos los miembros, tanto hombres como mujeres deben confesarse y comulgar para estar "(...) en gracia consigan la de Dios Nuestro Señor para que mediante en la diligencia y la yntervención del glorioso Santo tengan efecto nuestras oraciones" ${ }^{33}$.

La cuarta y la quinta ordenanzas son reveladoras respecto a la composición étnica de los miembros de la cofradía. Los españoles y mestizos -fueran hombres o mujerespagarán 1 peso, 8 reales y una libra de cera (en caso de no poder aportar la cera pagarán su equivalente que serían 2 reales). Estos datos deben ser anotados por el mayordomo en uno de los libros de la cofradía. Como era de esperar, los puestos de mayor importancia se reservan para los blancos y mestizos; no obstante, en el caso de mulatos, negros e indígenas quisieran formar parte de los hermanos de la cofradía, deberían pagar 4 reales de plata y una libra de cera, eso sí: “... los mayordomos los asienten en quaderno aparte del dicho libro y condición que no puedan ser electos por mayordomo y diputados" ${ }^{\text {34 }}$. Sin embargo, según consta en el libro de la cofradía ${ }^{35}$, el 10 de setiembre 1659 sobresale el hecho que indica:

(...) los dichos diputados pidieron a dicho señor Vicario diere permiso para que se nombre otros dos de los hermanos naturales, lo ubo por bien y en esta conformidad elixieron por tales diputados a Pedro Sambrano y Andres Roman y por mayordomo relegido a Esteban Rodríguez ${ }^{36}$.

33. AHABAT, Cofradías Cartago Caja N..$^{\circ}$ 3. Cofradía de San Nicolás de Tolentino.

34. AHABAT, Cofradías Cartago Caja N. ${ }^{\circ}$ 3. Cofradía de San Nicolás de Tolentino.

35. AHABAT, Cofradías Cartago Caja N. ${ }^{\circ}$ 3. Cofradía de San Nicolás de Tolentino.

36. AHABAT, Cofradías Cartago Caja N. ${ }^{\circ}$ 3. Cofradía de San Nicolás de Tolentino. 
Al año siguiente como diputados de los naturales se elige a Diego de Cárdenas y a Ambrosio de Torres. Con más claridad se muestra la expansión de la cofradía y la inclusión de miembros indígenas; y se destaca por la inclusión de mujeres en la elección del 9 de septiembre de 1679 bajo la forma de "patronas" En dicha sesión quedan electos como diputados el alférez Joseph de Calderón, el sargento Diego de Santiago, Pablo Sánchez y el capitán Lucas Cervantes, el mayordomo reelecto fue el capitán Francisco de Bonilla, como prioste el alférez Sebastián de Zamora; se incluyen las patronas doña Jerónima Abarca y doña Luisa ¿Cubillo?. Además, se adiciona a la lista de los diputados para los valles: Matina con el sargento Julio González Ochoa, para Barva el Teniente Alonso de Sibaja; Aserrí y Curridabat el alférez Diego de Chaves y para Esparza y Nicoya, don Gregorio Calvo. Los diputados por los naturales serán Cristóbal de Chaves Navarro y Antonio Morales, que se indica natural de Curridabat. La inclusión de personas de otras etnias y de las mujeres responde a la falta de cofrades, puesto que la institución se sustenta en parte con los aportes de sus miembros. De esta manera, es lógico que percibirán más ingresos, si permiten a más miembros, que ayudaran al pago de festividades, sermones y misas.

La participación de la élite de Cartago en los puestos políticos y eclesiásticos queda patente al revisar los apellidos de quienes forman parte de la cofradía, pues muchos se repiten a lo largo de todo el periodo colonial siendo hijos, nietos y bisnietos de encomenderos y miembros principales como alcaldes, regidores, alcaldes de Santa Hermandad o del cabildo entre otros. Claudia Quirós ${ }^{37}$ sostiene que todos los miembros fundadores de las cofradías del siglo XVI son encomenderos y los hermanos cofrades de las fundadas en el siglo XVII son en su mayoría su descendencia.

Así, los primeros miembros de la cofradía quedaron distribuidos en sus cargos de la siguiente manera:

Prioste: Andrés López de Céspedes.

Mayordomo: Francisco Solano y Juan López de Ortega.

Diputados: Cristóbal de Zapata, Domingo de Chavarría, Vasco Solano, Jerónimo de Retes, Juan Cascante de Retes, Juan de Ocampo Golfín, Juan Solano y Alonso de Sandoval.

Apellidos como Retes, Echavarría, Navarro, Ocampo, Golfín, Solano, Acuña entre otros; tendrán una aparición constante en documentos coloniales debido a su activa participación en la vida política, económica y religiosa de la provincia de Costa $\mathrm{Rica}^{38}$.

A partir de la sexta ordenanza, se aprecian los aspectos de la cofradía que se refieren a su dimensión asistencial y de organización comunitaria. San Nicolás de Tolentino como patrono podía brindar a sus devotos intercesión en momentos determinantes de la

37. Claudia Quirós Vargas, La era de la encomienda (San José: Editorial de la Universidad de Costa Rica, 1990), 8 .

38. Para información adicional respecto al papel de las élites se recomienda consultar: Eduardo Madrigal Muñoz, "Cartago República Urbana: élites y poderes en la Costa Rica colonial 1564-1718." Tesis de Doctorado, Universidad de Costa Rica, 2006. 
vida y la muerte; pues se le pide ayuda durante la maternidad, para los niños, las enfermedades, la buena muerte y por supuesto, para el paso de las ánimas del purgatorio al Paraíso. La solidaridad colectiva podía presentarse en dos momentos: en vida, cuando se otorgaba asistencia financiera (en forma de crédito) o se ayudaba materialmente con bienes se visitaba a los hermanos enfermos, y en el peor de los casos con el fallecimiento, en los gastos del entierro (sobre todo si se trataba de un hermano de escasos recursos) y la familia que dejaba: las viudas y huérfanos no quedaban desamparados. La otra ayuda es la calificada como ultraterrena. En caso de fallecimiento de uno de los miembros de la cofradía, el resto de los hermanos acompañaban el cuerpo hasta el sitio donde será enterrado. A partir de ese momento, los vivos velan por el tránsito de las almas de los muertos. Anualmente, un día después de la festividad de San Nicolás se efectuaba una vigilia y responso por los cofrades vivos y los difuntos, cada mes dos misas rezadas por los difuntos. Mario Humberto Ruz establece la función que en lo ultraterreno tenían las cofradías en el mundo maya colonial "(...) honras fúnebres dignas y sobre todo, contribuir al bienestar ultraterreno de los ya idos, colaborando de esa manera en el mantenimiento de la memoria de los antepasados" ${ }^{39}$, aspecto que se puede destacar, comparte con la cofradía de San Nicolás, muy a pesar de no tratarse de una cofradía indígena.

Al respecto, Oscar Ramírez Samayoa indica que la asociación entre las cofradías penitenciales y la devoción a las ánimas, podían confluir en un interés común ya que se tiene su origen en el concilio de Trento como parte de la visión de la vida terrena como un paso transitorio mientras que la vida ultraterrena era eterna e iniciaba con la muerte de la carne:

Sobre esta base escatológica se estableció la creencia en el purgatorio. La Iglesia militante (los vivos bautizados), estaba obligada a rezar, ofrecer penitencias y sobre todo celebrar misas (acto de culto central de la liturgia y adoración a Dios) por los difuntos (Iglesia purgante), para que ganaran indulgencias y así alcanzar la gloria y pasar a formar parte de la Iglesia Triunfante, que a su vez velaría y pediría por ésta. Para este fin se fundaron cofradías con el nombre de las "Animas Benditas del Purgatorio"40.

La asistencia a las almas del purgatorio fue impulsada por la Iglesia desde la Edad Media. Con la obra de Hugo Ripelius (1268) en el cual establece cinco sitios a los cuales las almas pueden llegar luego de la muerte: uno de descanso final (Paraíso) y cuatro de castigo (infierno, limbo, purgatorio y limbuspatrum ${ }^{41}$ ). La posibilidad de salir de ellos se ve influido por la descendencia que se preocupa de pagar misas y rezar por sus antepasados, o en el caso de la cofradía por los hermanos cofrades vivos.

En el aspecto financiero, la novena ordenanza establece una de las formas en las que la cofradía podría aumentar su capital. El día sábado de cada semana, se pediría limosna por la ciudad de Cartago, incluyendo a las chácaras y hatos cercanos, de esto estaría

39. Mario Humberto Ruz, "Una muerte auxiliada. Cofradías y hermandades en el mundo maya colonial", Relaciones. Estudios de historia y sociedad XXIV, N. ${ }^{\circ}$ 94, (primavera 2003): 19.

40. Oscar Gerardo Ramírez Samayoa, "Ordenanzas de cofradías penitenciales de Semana Santa en Santiago de Guatemala, siglo XVII”, en Boletín de la AFEHC n51 (Octubre-Diciembre de 2011). Disponible en http://www.afehc-historia-centroamericana.org/index.php?action=fi_aff\&id=3010

41. En este sitio llegaron las almas de los justos que murieron antes de la resurrección de Jesucristo. 
encargado un cofrade comisionado por el diputado que por elección le correspondiera esta tarea ${ }^{42}$; los fondos recogidos estarían a cargo del mayordomo que llevaría la cuenta en los libros. También una vez al año, se pediría por toda la provincia ya fuera en los pueblos, hatos, obrajes, salinas y estancias de ganado. De esta manera, los fondos recaudados de esta manera se destinarían para los gastos de ornamentación. Estas cuentas serían revisadas anualmente por el Vicario.

Pero esta no era la única vía de financiamiento de la cofradía, ya que los hatos de ganado vacuno y caballar, así como las plantaciones de cacao ofrecían medios para aumentar su capital en plata y en cacao, ya que podían comprar y vender ganado y subproductos como cebo para candelas, cueros, queso, jabón entre otros; así también por las ganancias que percibían al ser una fuente crediticia. Como era característico del período, los bienes estarían guardados en cajas, la cofradía poseía dos cada una con llave y que manejaría el mayordomo. En una quedarían a resguardo los libros ${ }^{43}$, en la otra la cera, estandartes y demás ornamentos que son bienes de valor como cálices, alhajas del santo, telas, imágenes entre otros.

Como se mencionó, el segundo momento en que la cofradía se reúne o hace "cabildo" es el primer domingo de cuaresma. En dicha fecha, todos los hermanos junto con el Vicario o cura, acordarán el orden y recorrido para la procesión de sangre que será realizada el viernes siguiente por la ciudad e iglesias de Cartago. Esta reunión que será convocada por un hermano vestido de túnica blanca y capirote a las dos del día de dicho domingo, y dará la vuelta por la ciudad tocando un esquilón ${ }^{44}$ y llevando en la mano una insignia del santo.

Ya en la procesión, el orden será el siguiente:

Yten es ordenanza, que para prozeción han de salir los disciplinantes y demás cofrades que huvieren de llevar las ynsignias y demás ornato, vestido con túnicas blancas y capirote, cubiertos los rostros con su sinto y escapulario negro estrellado descalsos con toda honestidad y modestia sin llevar particular insignia para hazer conocidos, y si alguno, por su devoción que se tiene hirhaziendo alguna penitencia de le de lugar, como a los demás hermanos y aquel día abra sermon antes de salir dicha prozeción, por el predicador que huviere ${ }^{45}$.

De igual forma se indica cuánto se pagará de limosna al párroco acompañante, al sacristán que irán "cantando en canto de órgano el tono el salmo de mísere o letanías", los demás hermanos después de haberse disciplinado, a costa de dicha cofradía y un trago de vino y que el mayordomo tenga para aquel día preparado en la capilla o iglesia; como es costumbre en este tipo de procesiones, quienes por un motivo de peso no participaran

42. La tarea de supervisar la recolección de limosna estaba dividida entre los 4 diputados, por lo que a cada uno le correspondía tutelar a la persona encargada durante tres meses, luego de lo cual, la tarea pasaría al siguiente diputado y así sucesivamente hasta terminar con su nombramiento anual.

43. En la ordenanza onceava establece el uso de tres libros: uno con el asentamiento de los cofrades de forma tal "con dos abecedarios, uno para los españoles y mestisos y otro para la demás gente, para que haya distinción y claridad", en el otro se anotaría la carga y la data (ingresos y egresos). AHABAT, Cofradías Cartago Caja N. ${ }^{\circ} 3$. Cofradía de San Nicolás de Tolentino.

44. Cencerro de gran tamaño.

45. AHABAT, Cofradías Cartago Caja N. ${ }^{\circ}$ 3. Cofradía de San Nicolás de Tolentino. 
como disciplinantes asistirán a sus compañeros y se encargarán de curar las heridas (lo cual se hacía con una mezcla de vino preparado con hierbas y especias $)^{46}$.

Para el segundo viernes de Cuaresma, a las dos de la tarde se vuelve a convocar a la procesión por medio del repique de la campana del templo parroquial o de la de San Nicolás. Una trompeta ronca y destemplada se tocará por las calles de la ciudad por cerca de una hora para que los cofrades se reúnan en la capilla y se preparen para una prédica a las 3 de la tarde y luego de la cual saldrán en procesión.

Primero saldrá un cofrade con su insignia de penitente y tocando delante una trompeta, luego un esquilón y otro con un estandarte negro con una cruz colorada; este lo debe de llevar una de las personas principales, como el estandarte trae una borla a cada lado, otras dos de las personas principales le acompañaran a los lados. Luego algunos penitentes y detrás de ellos una persona llevará una cruz grande negra con una toalla blanca pendiente de los brazos una insignia de la cofradía, luego un cristo crucificado y dos hermanos llevarán cirios encendidos (hermanos de luz); luego otro estandarte negro arrastrando por el suelo, seguido de penitentes y una serie de cofrades que llevarán los elementos que se relacionan con la iconografía distintiva de San Nicolás: una fuente con una calavera, otra con un cilicio de fierro, otra con una disciplina de abrojos y otra con una tórtola o perdiz de "bulto". Para finalizar, les seguirá otro grupo de penitentes y como cierre, la imagen de San Nicolás en andas.

Todos estos elementos mencionados son los que facilitan la identificación del santo, por eso la dimensión simbólica era determinante, no solo porque ofrecía dramatismo y ritualidad a las procesiones, sino porque hay que recordar que durante el período colonial, el papel de la imagen como parte de un código visual destinado a instruir a las masas analfabetas y poco ilustradas en los asuntos teológicos fue particularmente útil durante las prácticas religiosas en el Nuevo Mundo. De la misma manera que los catecismos de piedra que se encontraban en las iglesias del románico y del gótico europeo; la religiosidad barroca que con gran fastuosidad se instaura en América utiliza como recurso "didáctico" a las imágenes procesionales y a las escenas bíblicas que se llevan en andas.

Debido a lo delicado del transporte de este tipo mercancías y de lo costoso que podía resultar encargarlas, ya fuera a los talleres españoles, guatemaltecos, novohispanos o peruanos; lo más funcional era traer las llamadas imágenes de "palo" o de vestir. Estas por lo general consistían únicamente en la cabeza y las manos de la imagen, por lo que sus rasgos característicos se daban por medio de los trajes, coronas, potencias y entre otros. De ahí que la cofradía rápidamente comprara el hábito estrellado, la perdiz, la calavera y el cilicio como elementos característicos de la iconografía de San Nicolás de Tolentino.

46. Para el caso de las procesiones de sangre o penitenciales en Sevilla y Nueva España, Jesús Miguel Palomero Páramo indica: “... al regresar la Cofradía de su estación estaban preparadas en capilla varias vasijas grandes con vino hervido, arrayán en polvo, laurel, rosas, violeta y romero para que se lavaran las heridas; que se habían hecho durante el trayecto, siendo asistidos en esta operación por aquellos hermanos que, por diferentes causas, no hubiesen concurrido a la procesión; y si de estos no había, entonces los de luz cumplirían esta misión”. Al respecto consúltese el texto completo: Jesús Miguel Palomero Páramo, "Las procesiones de "sangre" en Sevilla y Nueva España. A propósito de una pintura mural en la iglesia conventual de Huexotzingo," en Actas de las I Jornadas de Andalucía y América, Instituto de Estudios Onubenses: (Sevilla: S.E, 1981), 314-321. 
Está claro que el orden y los elementos simbólicos resultan claves para otorgarle la seriedad que corresponde. El primer inventario que aparece en el libro de la cofradía ${ }^{47}$ data de 1675 y fue realizado por el mayordomo Nicolás de Barrantes. La cantidad de bienes con los que ya contaban y entre los que podemos destacar es significativa:

- Dos casullas para el santo, una de penitente y otra de las festividades.

- Tres pares de andas con sus vestiduras

- Un estandarte azul con cruz de plata, uno negro y otro con cruz colorada.

- Las fuentes con la perdiz, el cilicio y la calavera.

- Cuatro insignias para la procesión

- Varas de listones, telas y lienzos. Un paño de tela negro para los entierros.

- Un palio de ruan labrado.

- 4 libros de la cofradía

- Una lámpara y un vaso de plata.

- Una cruz negra de madera labrada con su sabanilla de ruan.

- Once túnicas con sus capirotes.

- Dos cajas de madera

- 15 libras de cera, entre otros bienes.

En general, por medio de las ordenanzas se regía la vida festiva y económica de la cofradía. Gastos, miembros y festividades debían consignarse en los libros y las ordenanzas debían de ser observadas al pie de la letra. Como espacio de sociabilidad, la cofradía da cabida todos los que se llamen devotos de San Nicolás. Sin embargo, participarán de manera diferenciada según su condición étnica y su puesto en la sociedad cartaginesa.

\section{Conclusiones}

La diversidad patronal que se puede encontrar a lo largo de todo el territorio americano respondía a una necesidad de protección en varios frentes. Cada santo(a), cada advocación mariana y cada misterio cristológico ofrecían apoyo en un aspecto distinto de la vida de los devotos y la elección de los patronos no dependía únicamente de las preferencias de las órdenes religiosas o del clero secular; también las devociones personales de los miembros de la élite fueron determinantes para su incorporación en la vida religiosa de la ciudad. A pesar de que San Nicolás era un santo cuya devoción fue impulsada principalmente por la orden de los agustinos, no fue impedimento para que tuviera una cofradía en territorio de los franciscanos, apareciendo de manera más temprana que la que se levantó en honor a San Francisco de Asís.

47. AHABAT, Cofradías Cartago Caja N. ${ }^{\circ}$ 3. Cofradía de San Nicolás de Tolentino. 
La cofradía de San Nicolás de Tolentino resultó ser una de tipo penitencial por su designación como cofradía de sangre y la práctica de autoflagelación durante las procesiones. De acuerdo con sus ordenanzas, contó con una organización vertical respecto a sus miembros debido a que los puestos de mayor prestigio estaban reservados para los españoles y sus descendientes (encomenderos, sus hijos y nietos); pues como es el caso del puesto de mayordomo, estaba destinado a quienes además detentaban o detentaron algún cargo público de importancia como lo era el de alcalde. A pesar del "anonimato" en sus prácticas establecido en las ordenanzas y regulado con el uso de túnicas con capirote y sin distintivos para evitar que se diese a conocer la identidad de los individuos que marchaban en las procesiones, las cofradías constituyeron un espacio de interés y de participación para los miembros de la élite cartaginesa.

En cuanto a la composición étnica se refiere, fue mixta ya que desde el principio se permite el ingreso -aunque con clara diferenciación- de indígenas, mulatos y negros los cuales se asentaban en libros diferentes, con la clara prohibición a los indígenas de ser electos mayordomos o diputados, hasta que en 1659 previo permiso del Vicario, se crea la figura del diputado de naturales. Aunque este hecho puede deberse a factores que no responden a criterios de "equidad e inclusión", sino más bien a manifestar criterios más prácticos, como la escasa cantidad de población -ya fuese blanca o mestiza- que constituía la cofradía y el requerimiento de una mayor cantidad de miembros para participar en las procesiones y festividades.

El carácter asistencial de la cofradía quedó reafirmado tanto en el ámbito terreno como en el ultraterreno, sobre todo debido a que su patrono era el abogado de las almas del purgatorio. El ayudar a los hermanos cofrades en vida durante los momentos difíciles como podía ser una enfermedad, daba sentido y cohesión dentro de la comunidad. Para facilitar el paso de la vida terrena a la vida eterna, la oración y misas por los hermanos fallecidos, ofrecían por medio del recuerdo de su paso por la tierra y por la intercesión de San Nicolás lograrán alcanzar la gracia eterna, por ser el abogado de las almas del purgatorio.

\section{ABSTRACT \\ The Orderly of a Bloody Brotherhood: The Brotherhood of Saint Nicolas of Tolentino, 1641}

This article briefly exposes the orderly responsible for the establishment of Nicolas of Tolentino brotherhood in 1641 at the city of Cartago, Costa Rica, based on the annotations of the Orderly book.

Key words: Cartago, brotherhood, orderly, patron saint, Costa Rica

RÉSUMÉ

Les ordonnances d'une confrérie du sang: la confrérie de de Saint Nicolas de Tolentino, 1641

Cet article expose brièvement les ordonnances qui ont conduit à l'établissement de la Confrérie de Saint Nicolas de Tolentino en 1641 dans la ville de Cartago au Costa Rica. Ceci, d'après ce qui est écrit dans le livre de la Confrérie.

Mots-clés: Cartago, confrérie, ordonnances, saints patrons, Costa Rica 


\section{Bibliografía}

\section{Fuentes primarias documentales e impresas}

Archivo Histórico Arquidiocesano Bernardo Augusto Thiel (AHABAT), Cofradías Cartago Caja N. ${ }^{\circ} 3$.

Diccionario de derecho canónico arreglado a la jurisprudencia eclesiástica española antigua y moderna. (París, Librería Rosa y Bouret, 1854).

Fernández, León. Colección de documentos para la historia de Costa Rica, Tomo VIII. (París: Imprenta de Pablo Dupond, 1886).

López de Ayala, Ignacio. Sacrosanto y ecuménico Concilio de Trento, traducido al idioma castellano por don Ignacio López de Ayala, Agregase el texto latino corregido según la edición auténtica de Roma, publicada en 1564.

Real Academia Española, Diccionario de autoridades, (España: Real Academia Española, 1734).

"Visita pastoral del Obispo Pedro Agustín Morel de Santa Cruz a la Diócesis de Nicaragua y Costa Rica, realizada en el año de 1751 y 1752", Revista Conservado$r a$, Managua, editorial Alemana N. ${ }^{\circ}$ 82, (julio 1967). Consultado en el Boletín de AFECH N. ${ }^{\circ} 38$ en el siguiente enlace: http://www.afehc-historia-centroamericana. org/?action=fi_aff \&id $=2026$

\section{Fuentes secundarias}

Beinert, Wolfgang. «Del purgatorio y otros lugares tenebrosos del más allá», Selecciones de teología, 2009, N. ${ }^{\circ}$ 190: 83-95.

Blanco, Ricardo. Obispos, arzobispos y representantes de la Santa Sede en Costa Rica. (San José: Editorial de la Universidad Estatal a Distancia, 1984).

Carvajal, Ligia y Guillermo Arroyo. «La cofradía en el Valle Central, principal obra pía de la colonia» (Tesis de Licenciatura, Universidad de Costa Rica, 1985).

García- Cárcel, Ricardo. «De la reforma protestante a la reforma católica. Reflexiones sobre una transición», Manuscrits: revista d' historia moderna, N. ${ }^{\circ}$ 16, (1998): 39-64.

Gómez, Emilio. «Santos intercesores del purgatorio: representaciones pictóricas en las Cofradías de Ánimas murcianas». En El culto a los santos: cofradías, devoción, fiestas y arte, (S.L: Ediciones Escurialenses, 2008), 491-506.

González, Yamileth. «Desintegración de bienes de cofradías y de fondos píos en Costa Rica, 1805-1845». Mesoamérica 5, N. ${ }^{\circ} 8$ (1984): 279-303.

Madrigal, Eduardo. «Cartago República Urbana: élites y poderes en la Costa Rica colonial 1564-1718» (Tesis de Doctorado, Universidad de Costa Rica, 2006).

Palomero, Jesús Miguel. «Las procesiones de "sangre” en Sevilla y Nueva España. A propósito de una pintura mural en la iglesia conventual de Huexotzingo». En Actas de las I Jornadas de Andalucía y América, (Sevilla: S.E, 1981).

Payne, Elizet; Claudio Vargas y Carmela Velásquez- Bonilla. Breve Historia de la Iglesia Católica en Costa Rica (1502-1992), (San José: Centro de Investigaciones Histórica de América Central, 1992). 
Peña, Ligia. «La situación de las cofradías en Nicaragua entre 1750-1810». Revista de Historia de Nicaragua, 14 (mayo 2002): 25-36.

Peña, Ligia. «Las cofradías indígenas en Nicaragua en el siglo XVIII-1812» (Tesis de Maestría en Historia, Universidad Centroamericana, 1997).

Pinto, Julio, [Ed]. Historia General de Centroamérica. Tomo II El régimen Colonial.1540-1750. (Barcelona: Ediciones Siruela, 1993).

Quirós, Claudia. «Las cofradías indígenas en Nicoya» Revista de Historia (Costa Rica) 36 (julio-diciembre 1997): 37-78.

Quirós, Claudia. La Era de la Encomienda. Colección Historia de Costa Rica. (San José: Editorial de la Universidad de Costa Rica, 1990).

Ragón, Pierre. «Los santos patronos en las ciudades de México Central (siglos XVI al XVII)» Historia Mexicana LII, N. ${ }^{\circ} 002$ (octubre-diciembre 2002): 361-389.

Ramírez, Oscar Gerardo. «Ordenanzas de cofradías penitenciales de Semana Santa en Santiago de Guatemala, siglo XVII», Boletín de la AFEHC N. ${ }^{\circ} 51$ (Octubre-Diciembre de 2011). Disponible en http://www.afehc-historia-centroamericana.org/ index.php?action=fi_aff $\&$ id $=3010$

Ruz, Mario Humberto. «Una muerte auxiliada. Cofradías y hermandades en el mundo maya colonial» Relaciones. Estudios de historia y sociedad XXIV, N. ${ }^{\circ} 94$ (primavera 2003).

Sanabria, Víctor Manuel. Reseña histórica de la Iglesia en Costa Rica, desde 1502 hasta 1850, (San José: Departamento Ecuménico de Investigaciones, 1984).

Sebastián, Santiago. Iconografía e iconología del arte novohispano. (Italia: Grupo Azabache, 1992).

Thiel, Bernardo Augusto. Datos cronológicos para la historia eclesiástica de Costa Rica, (San José: UNICLERO, 2002).

Velázquez Bonilla, Carmela. «El Sentimiento religioso y sus prácticas en la diócesis de Nicaragua y Costa Rica. Siglos XVII y XVIII» (Tesis de Doctorado, Universidad de Costa Rica, 2004).

Velázquez Bonilla, Carmela. «Los cambios político-administrativos en la diócesis de Nicaragua y Costa Rica. De las Reformas borbónicas a la independencia» Hispania Sacra LXII, N. ${ }^{\circ} 128$ (julio-diciembre 2011): 569-593.

Velázquez Bonilla, Carmela. «Santos Patronos y oraciones contra los temblores». En Efemérides de la destrucción de la ciudad de Cartago cien años después (19102010), ed. Geovanni Peraldo Huertas y Benjamín Acevedo. San José: Universidad de Costa Rica, Escuela Centroamericana de Geología, Red Sismológica Nacional UCR-ICE, 2010.

Webre, Stephen. «Poder e ideología: la consolidación del sistema colonial (1542-1700)». En Historia General de Centroamérica. Tomo II El régimen Colonial. 1540-1750. ed. Julio Pinto Soria (Barcelona, España: Ediciones Siruela, 1993). 